\section{THE POLITICS OF PRESS REGULATION}

"A sloppy, elephantine piece of work that relies on nobody having the time to read it before taking sides." This dismissal of Lord Justice Leveson's four-volume report, An inquiry into the culture, practices and ethics of the press (November 29, 2012), was delivered by Peter Preston, a former editor of the Guardian and an influential figure in the world of newspaper journalism. Mr Preston's views are shared by many editors and others within the media opposed to Leveson's central recommendation for the creation of an independent selfregulatory body underpinned by statute to regulate the press. Some have found the report much more to their liking, notably the Hacked Off campaign which represents those who consider themselves to have been victims of abusive practices by the press. Hacked Off wants Leveson to be implemented in full without delay, backed by a petition signed by over 100,000 people and supported by well-known figures such as the Harry Potter author J K Rowling and entertainer Stephen Fry.

Many politicians are also championing the report's recommendations, although not everyone in Westminster is convinced. The most notable dissenter is the Prime Minister, who regards statutory regulation of the press as a step too far and appears to view the Leveson report as a useful means of levering the press into devising an effective system of selfregulation if it can. Unfortunately it is not clear how such a system would work, as neither Mr Cameron nor the press have so far come up with workable alternatives to the status quo. The Deputy Prime Minister, Nick Clegg, publicly endorsed Leveson on behalf of the Liberal Democrats, and the Labour leader, Ed Miliband, rapidly committed his party's support. Some Conservative MPs side with their leader, but despite splits within the coalition a draft Bill based on Leveson is being prepared. Just to complicate matters further, Labour is understood to have started work on its own press regulation Bill in case reforms are blocked.

Lord Justice Leveson condemned "a culture of reckless and outrageous journalism" in some quarters, but has sought to balance press freedom with the rights of individuals affected by its activities. The independent self-regulatory body he recommends should be "free of any influence from industry and government" and administered by an independent board whose members must be "appointed in a genuinely open, transparent and independent way." Legislation creating the new regulator should allow it to be organised by the industry while placing "an explicit duty on the government to uphold and protect the freedom of the press." The regulator has been given the power to fine up to 1 per cent of an offender's turnover up to a maximum of $£ 1$ million, and the power to investigate suspected serious or systemic breaches of the code it is responsible for administering. This would enable it to take a much more proactive attitude towards allegations of widespread press misconduct, such as phone hacking, than the Press Complaints Commission.

\section{Articles}

The Common European Sales Law proposal - European Private law at the crossroads?

Interpreting the new South African Companies Act: some challenges

\section{Institute News}

\section{Articles (cont'd)}

Reducing overreliance on credit ratings; failing strategies and the need to start from scratch

Cameras in the courts: why the prohibition occurred in the UK

The report is long and detailed, but even those who confound Mr Preston's prediction and study its arguments in full are likely to base their support or opposition around a few key propositions and the issues they address. For example, newspapers will be free to opt out of the new system, but Leveson recommends that those who do should be policed instead by Ofcom, the communications industry regulator. Shami Chakrabarti, Director of Liberty and one of six assessors who worked on the Leveson inquiry, has already said that while she supports the system it has created she cannot approve any attempt to force legislative controls on the press if it fails to sign up voluntarily. In her view such a course of action could breach the Human Rights Act.

It is hard to see how anything Leveson recommends could be effective if sections of the press remained able to ignore attempts to regulate it. Richard Desmond, owner of $O K !$ and the Daily Express, has boycotted the Press Complaints Commission which he told the Leveson inquiry was "a useless organisation run by people who want tea and biscuits." It appears likely he would also ignore any successor to the PCC if given the chance. Strangely enough, by taking such a stance under Leveson in its present form he would find himself being supervised by Ofcom - which he already is in his capacity as owner of Channel 5.

There are other concerns over the proposed reforms, such as their perceived ineffectiveness in relation to the internet and social media, and the problems associated with preventing politicians from exerting influence over press regulation by influencing "independent" appointments to key positions. All that the various parties can agree on is that the Press Complaints Commission has failed and must be replaced. While the political game for their regulatory future is played, newspapers contemplate a much more intractable foe - the battle for economic survival in a declining market.

\section{Julian Harris}

Deputy General Editor, Amicus Curiae 